\title{
Neuroprotection Against Hypoxic/Ischemic Injury: $\delta$-Opioid Receptors and BDNF-TrkB Pathway
}

\author{
Shiying Sheng ${ }^{\mathrm{a}}$ Jingzhong Huang ${ }^{\mathrm{a}} \quad$ Yi Ren $^{\mathrm{a}}$ Feng Zhia Xuansong Tian ${ }^{\mathrm{b}}$ \\ Guoqiang Wenc Guanghong Ding ${ }^{\mathrm{d}, e}$ Terry C Xia ${ }^{f}$ Fei Hua ${ }^{a}$ Ying Xiad,e
}

aThe Third Affiliated Hospital of Soochow University, Changzhou, Jiangsu, 'bShanghai University of Traditional Chinese Medicine, Shanghai, cHainan General Hospital, Haikou, Hainan, 'Shanghai Key Laboratory of Acupuncture Mechanism and Acupoint Function, Department of Aeronautics and Astronautics, Fudan University, Shanghai, e'Shanghai Research Center for Acupuncture and Meridians, Shanghai, China, 'The University of Connecticut, Storrs, Connecticut, USA

\section{Key Words}

$\delta$-opioid receptor $\cdot$ BDNF $・$ TrkB $・$ Brain $・$ Hypoxia $・$ Ischemia $・$ Neuroprotection

\begin{abstract}
The delta-opioid receptor (DOR) is one of three classic opioid receptors in the opioid system. It was traditionally thought to be primarily involved in modulating the transmission of messages along pain signaling pathway. Although there were scattered studies on its other neural functions, inconsistent results and contradicting conclusions were found in past literatures, especially in terms of DOR's role in a hypoxic/ischemic brain. Taking inspiration from the finding that the turtle brain exhibits a higher DOR density and greater tolerance to hypoxic/ischemic insult than the mammalian brain, we clarified DOR's specific role in the brain against hypoxic/ ischemic injury and reconciled previous controversies in this aspect. Our serial studies have strongly demonstrated that DOR is a unique neuroprotector against hypoxic/ischemic injury in the brain, which has been well confirmed in current research. Moreover, mechanistic studies have shown that during acute phases of hypoxic/ischemic stress, DOR protects the neurons mainly by the stabilization of ionic homeostasis, inhibition of excitatory transmitter release, and attenuation of disrupted neuronal transmission. During prolonged hypoxia/ischemia, however, DOR neuroprotection involves a variety of signaling pathways. More recently, our data suggest that DOR may display its neuroprotective role via the BDNF-TrkB pathway. This review concisely summarizes the progress in this field.

(C) 2018 The Author(s) Published by S. Karger AG, Basel
\end{abstract}

\section{Introduction}

Hypoxic/ischemic injury remains the most dreaded cause of neurological disability and mortality. At present, however, clinical therapies against hypoxic/ischemic injury are

Ying Xia

and Fei Hua 
still very limited. Since the brain is extremely sensitive to hypoxia and ischemia, protecting brain tissue from injury (simplified as "neuroprotection") has therefore been a long sought after strategy in quelling physiological damage following stroke onset. Over the course of more than 30 years, abundant research efforts have been made to investigate over 1, 000 pharmacological neuroprotectants. Unfortunately, almost all attempts at protecting the brain from ischemic injury have failed at making a successful transition into clinical use. Therefore, it is important to better understand the mechanisms of neuroprotection and explore new strategies for the prevention and treatment of hypoxic/ischemic brain injury. As a result of this goal, we have recently found that the delta-opioid receptor (DOR) is an important neuroprotector against hypoxic/ischemic injury in the brain [1-4]

DOR is one of the three classic opioid receptors in the opioid system. Since its cloning in the early 1990s [5, 6], past functional studies were mostly focused on pain modulation and addiction [7-10]. Although scattered studies on other functions of DOR can be found in the literature, the outcomes and conclusions of these studies are inconsistent, and sometimes very contradictory. For instance, some studies suggested that opioid agonists were neuroprotective against hypoxic or ischemic injury [11-15], while others showed that opioid antagonists (e.g., naloxone, a non-selective opioid antagonist) had the same effect [16-19]. These controversies may be attributed to many factors including inappropriate methodologies and ligands.

In 1990s, we found that DOR density is much higher in the brain of a turtle that is highly tolerant to hypoxic/ischemic stress in comparison to the rat brain [20,21]. Such distinctive distribution of DOR between species prompted us to believe that DOR has unique functions, including brain protection against hypoxia/ischemia. Since then, we have conducted serial studies with diversified approaches including biochemical, molecular, transgenic, and electrophysiological techniques to investigate the role of DOR in the brain under hypoxic/ ischemic conditions and demonstrated that DOR is neuroprotective against hypoxic/ ischemic stress. Our findings have been confirmed by many independent investigators.

More recently, our work suggests that DOR may display its protective role though neurotrophic factors, especially brain-derived neurotrophic factor (BDNF) via tropomyosin receptor kinase B (TrkB). This review concisely summarizes the progress in the research on the role of BDNF in the DOR neuroprotection.

\section{Opioid receptors and endogenous opioids}

Opioids have been widely exploited for their potent analgesic and ecstasy-inducing effects in both medical and non-medical settings throughout a long history.

In the middle of the 1970s, Hughes and other scientists discovered the existence of various types of endogenous opioids - a family of chemically distinct endogenous compounds with properties similar to morphine, including enkephalins, endorphins, and dynorphins [22-25]. In the early 1980s, opioid peptide precursor genes were identified, proving the existence of the preproenkephalin gene that encoded several copies of enkephalins [26], the preprodynorphin gene encoding dynorphins [27], and the proopiomelanocortin gene encoding $\beta$-endorphin [28].

Opioid receptors were first recognized in the 1960s during pharmacological studies that focused on the specific sites at which opiates exerted their actions. Martin et al [29]. provided the first evidence of opioid receptors in vivo. In the early 1970s, the receptors were first identified by the use of radio-binding assay [30-32]. In late 1992, two groups independently cloned DOR from the neuroblastoma x glioma cell line NG-108 by using an expression cloning strategy. Both reported the identification of a novel member of the 7-helix family of G-protein coupled receptors that had pharmacological properties typical of DOR [5, 6]. Almost one year later, mu-opioid receptors (MOR) [33,34] and kappa-opioid receptors (KOR) [35, 36] were cloned as well.

\section{KARGER}


These opioid receptors are members of the rhodopsin subfamily in the superfamily of seven-transmembrane nucleotide binding regulatory G-protein coupled receptors (GPCRs) [1, 37, 38]. Although homology is present, they recognize structurally diverse exogenous/endogenous peptide and non-peptide ligands [39-41].They are distinctly distributed in both the central nervous system, especially in the cortical regions (Fig. 1), and peripheral organs [21, 25, 41-46]. Leu- and met-enkephalins constitute the main endogenous agonists. They are produced in many types of cells and preferentially bind to DOR in physiological concentrations [41, 47-49].

Pharmacological evidence indicated the existence of two distinct DOR subtypes:, $\delta 1$ and $\delta 2$ [50-52]. However, there exists only a single DOR gene for distinct subtypes of DOR [39]. DOR subtypes likely originate from a single DOR gene, and differ due to multiple affinity states or to posttranslational modifications at the

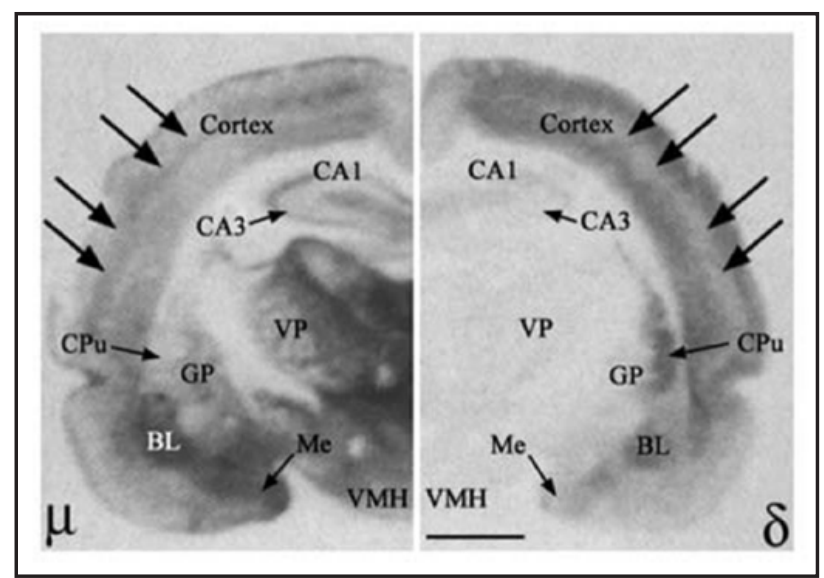

Fig. 1. Differential distribution of MOR (left) and DOR (right) in the rat rostral brain. BL, basolateral amygdaloid nucleus; CA1, field CA1 of hippocampus; CA3, field CA3 of hippocampus; $\mathrm{CPu}$, caudate putamen; GP, globuspallidus; Me, medial amygdaloid nucleus; VMH, ventromedial hypothalamic nucleus; VP, ventral posterior thalamic nucleus. Note that the distributional patterns of MOR and DOR are totally different with MOR having a high density in all major regions including subcortical areas and DOR having a much higher density in the cortex, caudate putamen and amygdala than most of the subcortical regions. Also note that there is a higher density of MOR in the middle layer than the outer and inner layers of the cortex, while the opposite is true for the density of DOR. The other cortical layers have an opposite pattern of expression. Scale bar $=2 \mathrm{~mm}$. Cited from Xia and Haddad [21]. protein level rather than at the gene level [39].Several endogenous opioids (including enkephalins, endorphins and dynorphins that originate from the same or different precursor proteins) can activate DOR with different binding affinities. However, it is unclear yet if there is any endogenous opioid antagonist. In the past three decades, many exogenous opioid agonists and antagonists have been used for DOR research. However, they differ widely with respect to their efficacies, potency, side-effects, clearance, and passage through the blood-brain barrier; refer to our previous articles [41,53]. To the best of our knowledge, UFP-512 (H-Dmt-Tic-NH-CH[CH2-COOH]-Bid) is the most potent and specific DOR agonist, and Naltrindole is a well-accepted DOR antagonist [41, 53-58].

Previous studies on the function of DOR were mainly focused on pain modulation and addiction with little conclusive information on its other functions [7-10]. Our recent studies have gained substantial data to show that DOR is a critical neuroprotector in the brain under hypoxic/ischemic conditions.

\section{Opioid receptors and neuroprotection: Major controversies in the past}

Before our work in this area, there was a major controversy on the role of opioids/ opioid receptors in the brain/neurons with hypoxia and/or ischemia.

Some studies suggested that opioid receptor inhibition with naloxone, a non-specific antagonist to DOR, MOR, and KOR [7, 41, 49], is neuroprotective against ischemic injury [16$19,59]$. 
In contrast, other studies implied that opioid receptor activation induced neuroprotection. Hayward et al $[11,12]$. reported the neuroprotective efficacy of a KOR agonist in two acute rat models of focal cerebral ischemia. However, Iwai et al. 's work did not support this notion [60]. They investigated the effect of opioids on delayed neuronal death in the hippocampus of male Mongolian gerbils subjected to transient forebrain ischemia, and found that treatment with the KOR agonist U-50488H, MOR agonist morphine, or naloxone did not induce any significant protection. However, Endoh et al [61]. reported that morphine had a protective action against acute hypoxia; i.e., increasing the survival rate of the mice subjected to acute hypoxia, while a high dose of naloxone decreased the survival rate. On the other hand, Mayfield et al [13-15]. showed that hypoxic conditioning increases survival time during subsequent lethal hypoxic conditions in mice; this protective effect was blocked by naloxone, suggesting an opioid-dependent mechanism. Furthermore, they reported that DOR-1 mediated the mechanism of hypoxic conditioning induced an increase in animal survival time; neither the MOR antagonist (beta-funaltrexamine), nor KOR antagonist (norbinaltorphimine) significantly changed survival time in sham or hypoxic conditioned mice. All these data contradicted the conclusion that "opioid receptor inhibition induced neuroprotection".

Closer examination of the literature caused even greater confusion. For example, some clinical studies $[62,63]$ showed that the efficacy of naloxone for the treatment of cerebral ischemia is inconclusive. Upon examination of the studies by Mayfield et al [1315]., it was unclear if "neuroprotection" was involved in increased survival time because an increased animal survival time following systemic administration of opioid ligands does not necessarily indicate "neuroprotection". Since DOR is widely distributed in the central and peripheral systems including the heart and kidney [41, 44, 49], an intravenous ligand may elicit systemic effects through many complex and varied mechanisms. The change in survival time may have resulted from the diverse effects of opioid ligands on various organs and organ systems, especially in the heart and kidney [64-71].

In addition, limited data from some in vitro studies [72,73] still did not clear up the confusion over the above-mentioned controversies. First, the results were not consistent with those of in vivo studies. Secondly, the limited studies contradicted each other - one claimed a "non-opioid" effect while the other argued for a KOR protective effect. Third and most importantly, there is no convincing data on the role of DOR in neuroprotection against hypoxic/ischemic injury.

The outcome of previous studies varied in all aspects, and depended on many factors including the conditions of subjects, dose and specificity of opioid ligands used, time point of assessment, accuracy of measurements, and etc.

\section{ठ-opioid receptor: A neuroprotector against hypoxic/ischemic injury}

In our early studies on the differences in hypoxic/ischemic tolerance between mammalian and freshwater turtle brains [20,74-76], we found that the turtle brain has a higher density of DOR and a higher binding affinity with its ligand than the rat brain [21]. In contrast, other membrane proteins, such as $\mathrm{Na}+$ channels [77] and sulfonylurea receptors [42], did not show this phenomenon.

Based on the observations on the turtle brain that showed a much higher DOR density [21] and greater tolerance to hypoxic/ischemic insult than the rat brain $[20,74-76,78]$, we believe that DOR plays a unique role in neuroprotection against hypoxic/ischemic injury.

We therefore attempted to determine if DOR is neuroprotective against hypoxic/ ischemic injury with a reliable model. Since the cortex is rich in DOR expression compared to subcortical regions such as the hippocampus (Fig. 1) [21, 42], we specifically cultured cortical neurons and exposed them to hypoxia or glutamate excitotoxicity and then determined if DOR activation attenuates hypoxia- and glutamate-induced neuronal injury $[4,79,80]$. We applied [D-ala2, D-leu5] enkephalin (DADLE), a popular and commercially

\section{KARGER}


available DOR agonist at that time, to evaluate its effect on the neurons. The data showed that DOR activation with DADLE indeed reduced hypoxia or excitotoxicity induced injury $[4,79,80]$. At the same time, Borlongan et al [81]. also showed that DADLE protects against ischemia reperfusion damage in the striatum and cerebral cortex.

However, it was extremely difficult to come to a reliable conclusion about the role of DOR in neuroprotection simply based on the data of DADLE, because DADLE is not highly specific to DOR and might bind to other opioid receptors. For example, it binds to MOR sites and inhibits the binding of DMGO, a MOR ligand, in a competitive manner [82].

Therefore, we further clarified the actions of DOR on neuronal responses to excitotoxicity by directly applying other various opioid agonists and/or antagonists to cultured cortical neurons to compare their effects on glutamate-induced neuroexcitotoxicity. We found that Naltrindole, a DOR antagonist, completely blocked the protective effect offered by DADLE. In contrast, administration of MOR agonist DAMGO had no protective effect, while MOR antagonists did not significantly affect glutamate-induced injury either. KOR agonist U50, 488H induced a slight, but not significant, reduction in neuronal injury, while KOR antagonism also had no appreciable effect on glutamate-induced injury [4, 79]. After this work, we were inclined to believe that activation of DOR, but not MOR nor KOR, induced neuroprotection against glutamate excitotoxicity in cortical neurons. Soon after, we observed similar protection in the cortical neurons exposed to hypoxia [80]. Consistently, our electrophysiological studies with UFP-512 (H-Dmt-Tic-NH-CH[CH2-COOH]-Bid) [54], a more potent and specific DOR agonist, also showed that DOR is relatively specific in the protection against anoxic disruption of ionic homeostasis because MOR activation was not shown to induce any protective effect [55]. Furthermore, our transgenic studies showed that cortical DOR overexpression attenuated anoxia-induced disruption of ionic homeostasis, suggesting that an increase in DOR expression renders the cortex more tolerant to hypoxic stress [83].

Our strong evidence indicates that DOR is a unique neuroprotector against hypoxic/ ischemic stress in the brain. Also, there have been abundant data thereafter showing DOR neuroprotection from many independent laboratories worldwide [84-105].

\section{DOR neuroprotection via BDNF-TrkB pathway}

Recent data from our laboratory and among others have presented some groundbreaking mechanisms involved in DOR neuroprotection against hypoxic/ischemic brain injury. During acute phases of hypoxic/ischemic stress, DOR protects the neurons mainly by the stabilization of ionic homeostasis, inhibition of excitatory transmitter release, and attenuation of disrupted neuronal transmission. During prolonged hypoxia/ischemia, however, DOR neuroprotection involves a variety of signaling pathways $[2,3,106]$.

Neurotrophic factors constitute an important element in determining the fate of neurons under hypoxic/ischemic insults. Our recent studies suggest that some neurotrophic factors (NTFs) such as brain-derived neurotrophic factor (BDNF) are important for DOR-mediated neuroprotection.

Indeed, BDNF is co-localized with DOR in DOR-rich regions in the brain. Using fluorescence immunolabeling, we determined the localized distribution of DOR and BDNF in the cortex and striatum. The BDNF-labeled cells (exhibiting neuronal-like morphology) were found in the cortex and striatum with an abundant distribution in the frontoparietal cortex and lateral caudate putamen in the sham-operated group (Fig. 2A). Triple-labeled confocal images also showed that BDNF and DOR/MAP-2 protein were co-localized in the neuronallike cells in the frontoparietal cortex (Fig. 2B, C) [107].

\section{DOR upregulates BDNF and TrkB in hypoxia}

Both in vivo and in vitro studies have demonstrated BDNF-induced neuroprotection against hypoglycemia, ischemia, and hypoxia $[108,109]$. Since DOR is highly expressed in cortical and striatal regions $[20,21]$, we further investigated if DOR protects them from hypoxic injury through BDNF [110]. 


\section{Cellular Physiology Cell Physiol Biochem 2018;47:302-315 \begin{tabular}{l|l} 
DOI: 10.1159/000489808 & and Biochemistry \\
Published online: May 17, 2018 & $\begin{array}{l}\text { O 2018 The Author(s). Published by S. Karger AG, Basel } \\
\text { www.karger.com/cpb }\end{array}$
\end{tabular}

To determine if DOR-induced protection against prolonged hypoxia in cortical regions involves the BDNF pathway, we investigated the effect of DOR activation on the expression of BDNF and other proteins in the cortex of C57BL/6 mice exposed to hypoxia $(10 \%$ of oxygen) for 1-10 days. We observed that 1-day hypoxia had no appreciable effect on BDNF expression, while 3- and 10-day hypoxia progressively decreased BDNF expression, resulting in a $37.3 \%$ reduction $(\mathrm{p}<0.05)$ after 10 -day exposure. DOR activation with UFP-512 $(1 \mathrm{mg} /$ $\mathrm{kg}$, i.p., daily) partially reversed the hypoxia-induced reduction of BDNF expression in the 3- or 10-day exposed cortex.

The BDNF-mediated effect is mediated through activation of $\operatorname{TrkB}$, a high-affinity tyrosine kinase receptor [111-113]. TrkB has two major types of isoforms: a full-length TrkB protein that possesses a tyrosine kinase domain, and a truncated isoform that lacks this domain [108]. Upon activation by BDNF, full-length TrkB undergoes autophosphorylation to regulate Erk/MAPK signaling, which may increase cAMP and activate CREB-regulated gene transcription, which further promotes transcription of BDNF. This is a positive feedback mechanism where BDNF induces the synthesis of BDNF itself (Yoshii and Constantine-Paton, 2010). We therefore determined if DOR activation affects TrkB. Our data showed that DOR activation partially reversed the hypoxia-induced reduction in functional TrkB (140-kDa) and attenuated hypoxia-induced increase in truncated TrkB $(90-\mathrm{kDa})$ in the cortex exposed to 3- or 10-day hypoxia.

With the downregulation of BDNF and TrkB after prolonged hypoxia, the level of tumor necrosis factor- $\alpha$ (TNF- $\alpha$ ) increased. After 10-day hypoxia, it significantly increased in the cortex, which was completely reversed following DOR activation (Fig. 3).

Our results suggest that prolonged hypoxia down-regulates BDNF-TrkB signaling, leading to an increase in TNF- $\alpha$ in the cortex, while DOR activation up-regulates BDNFTrkB signaling, thereby decreasing TNF- $\alpha$ levels in the hypoxic cortex. Since TNF- $\alpha$ is known to induce neuroinflammation and neurotoxicity in the hypoxic/ischemic brain, DOR neuroprotection is likely mediated, at least partially, by upregulating BDNF-TrkB signaling and thus reducing TNF- $\alpha$ neurotoxicity.

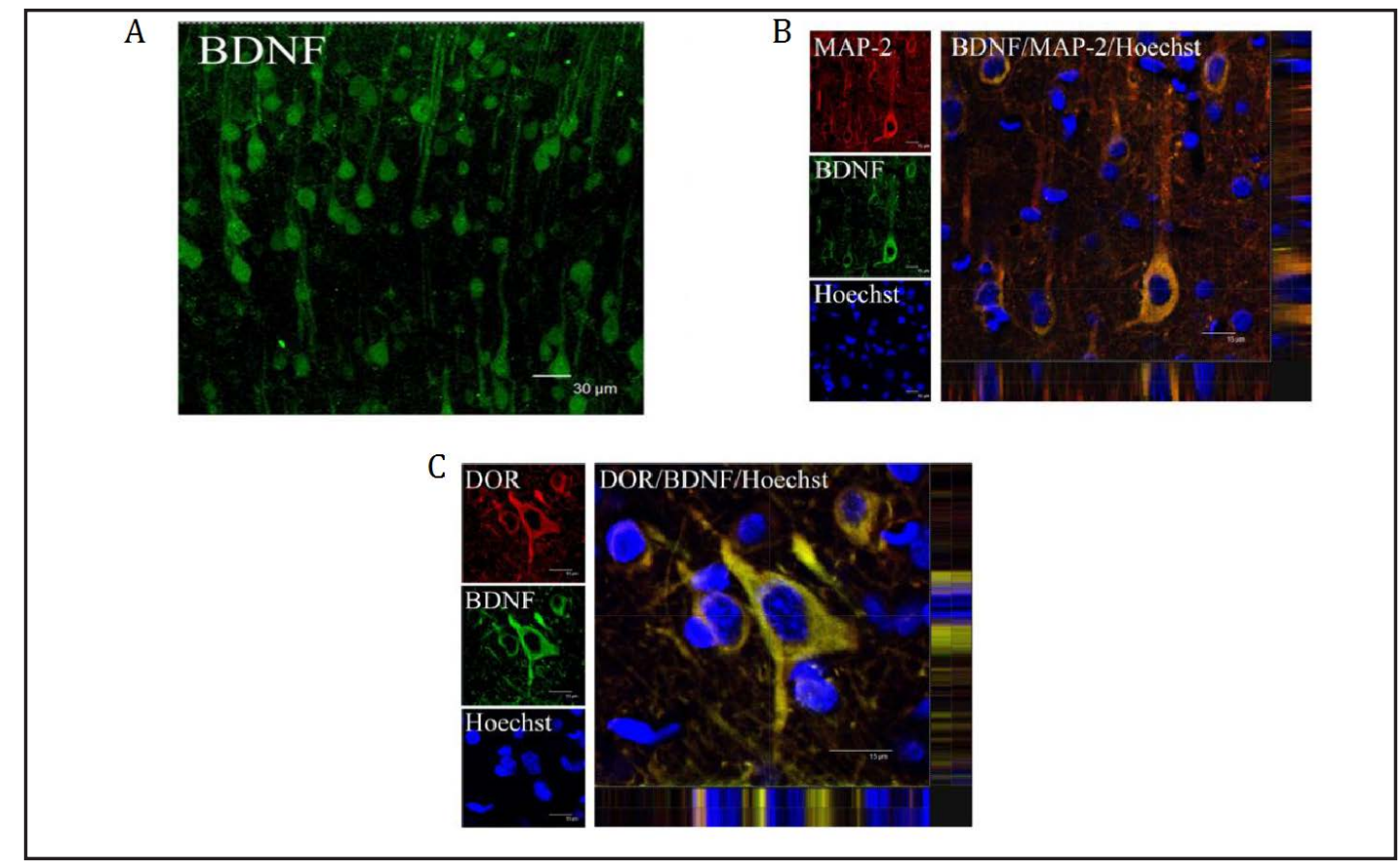

Fig. 2. Co-localization of BDNF and DOR in cortical neurons. Top panel, Fluorescent micrographs of cortical BDNF positive cells. Bar $=30 \mu \mathrm{m}$. Middle panel, Fluorescent micrographs of cortical BDNF/MAP-2 doublelabeled positive cells. Bar $=15 \mu \mathrm{m}$. Bottom panel, Fluorescent micrographs of cortical BDNF/DOR doublelabeled positive cells. Bar $=15 \mu \mathrm{m}$. Cited from Tian et al. [110]. 
Fig. 3. Effect of DOR activation on cortical TNF- $\alpha$ expression in hypoxia. Top panel, Representative blots of Western blot analysis of the cortical tissues. Bottom panel, Relative levels of TNF- $\alpha$. C, Normoxic control. H, Hypoxia. C + U (UFP-512, a DOR agonist), DOR activation with UFP-512 in normoxic condition. $\mathrm{H}+\mathrm{U}$ (UFP-512), DOR activation with UFP-512 in hypoxic condition. $\mathrm{N}=4,5$ and 6 for 1,3 and 10 days groups, respectively. ${ }^{*} \mathrm{p}<0.05$ vs. the control. $\# \mathrm{p}<0.05$ vs. $\mathrm{C}+\mathrm{U}$ (UFP-512). $\Delta \mathrm{p}<0.05$ vs. $\mathrm{H}+\mathrm{U}$ (UFP-512). Note that 10 days hypoxia significantly increased the level of TNF- $\alpha$, while DOR activation completely inhibited such increase. Cited from Tian et al. [110].

DOR activation reverses ischemic downregulation of TrkB

In another study [107], we further investigated if DOR modulates

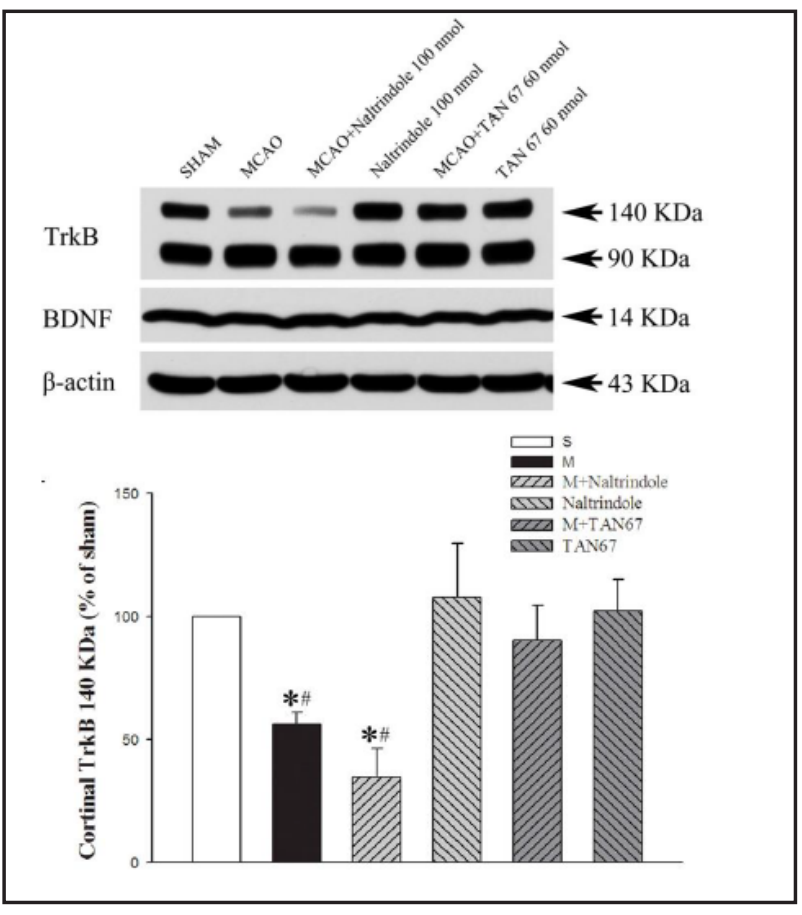
the BDNF-TrkB pathway in cerebral ischemia.

We exposed adult male Sprague-Dawley rats to focal cerebral ischemia, which was induced by middle cerebral artery occlusion (MCAO). DOR agonist TAN-67 (60 nmol) or antagonist Naltrindole $(100 \mathrm{nmol})$ was injected into the lateral cerebral ventricle $30 \mathrm{~min}$ before MCAO. We measured ischemic injury anddetected the expression of BDNF, full-length and truncated TrkBat 24 hours after MCAO. Our results showed that MCAO caused a large volume of ischemic infarct and significantly decreased full-length TrkB protein expression, while DOR activation with TAN-67 significantly reduced the size of ischemic infarct and largely reversed the decrease in full-length TrkB expression in the ischemic cortex (Fig. 4) and striatum (Fig. 5) without any appreciable change in cerebral blood flow. Meanwhile, the DOR antagonist, naltrindole, aggregated the ischemic injury.

Interestingly, the levels of BDNF remained unchanged in the cortex, striatum, and hippocampus at 24 hours after MCAO and did not change in response to DOR activation or inhibition. This notion is slightly different from that under hypoxic conditions [110]. Since we did not observe any significant changes in BDNF in the cortex after 24 hours of hypoxic exposure, it is likely that BDNF, as a neuroprotective factor in the cortex, is maintained at a relatively stable level for the purpose of neuroprotection. Therefore, no appreciable changes were found in tissues sampled from the brain at 24 hours after ischemia. In contrast to BDNF, TrkB seems more sensitive to ischemic stress. This is based on the notion that full-length functional TrkB protein was significantly reduced in the cortex at 24 hours after ischemia, while it did not have a significant change in the same region after exposure to hypoxia for 24 hours [110].All these data suggest that DOR activation rescues TrkB signaling by reversing ischemia/reperfusion induced decrease in the full-length TrkB receptor and reduces brain injury in ischemia/reperfusion

\section{DOR activation increases astrocytic BDNF expression}

BDNF, nerve growth factor (NGF), and glial cell line-derived neurotrophic factor (GDNF) are expressed in both neurons and astrocytes. Both astrocytic and neuronal NTFs are thought to enhance the growth, functional maintenance, and phenotypic development of neurons and play a crucial role in brain protection against hypoxic/ischemic encephalopathy and neurodegenerative diseases. However, there was no published information available in 


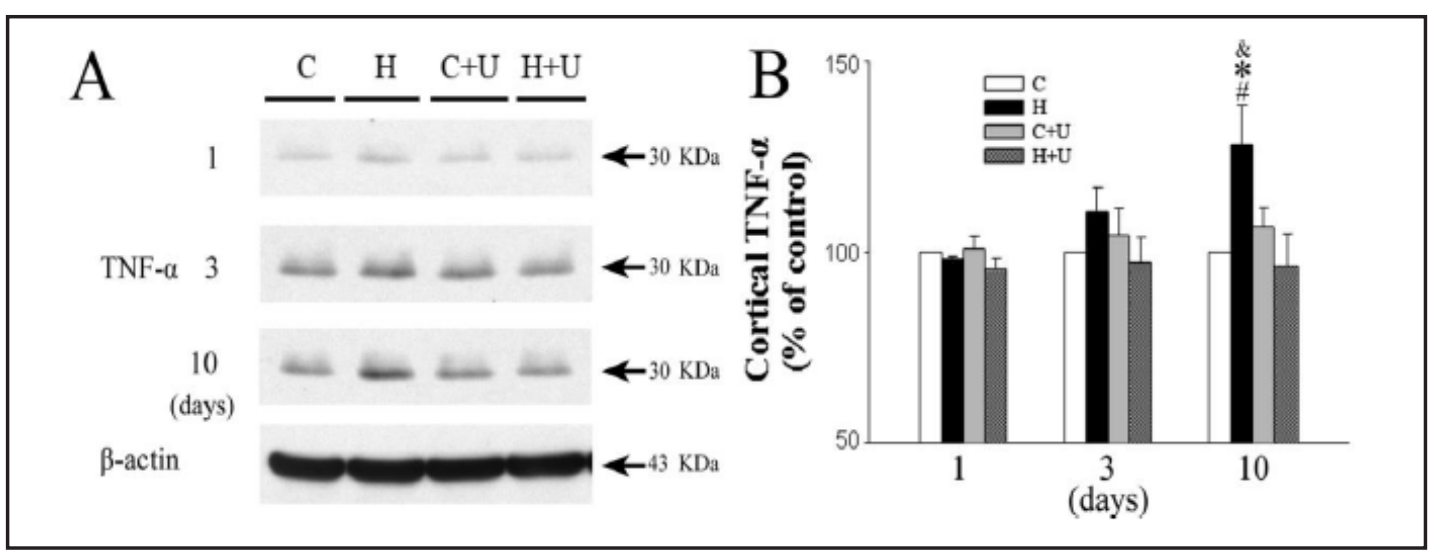

Fig. 4. Effects of DOR activation and inhibition on cortical TrkB at 24 hrs after MCAO. A, Representative Western blot images of TrkB expression in different groups. B, Quantitative analysis of $140 \mathrm{KDa}$ full-length TrkB ( $\mathrm{n}=4$ ). S, Sham control. M, MCAO. ${ }^{*} \mathrm{P}<0.05$ vs. the sham control. \#P<0.05 vs. M + TAN67 (a D0R agonist). Note that MCAO significantly reduced the expression of $140 \mathrm{KDa}$ TrkB in the cortex, while DOR activation with TAN67 largely reversed such ischemic reduction. Cited from Tian et al. [107].

the literature in terms of the interaction between DOR and NTFs in astrocytes before our work [114]. We therefore cultured pure astrocytes from the mouse brain and studied the effect of DOR activation by UFP-512, a potent DOR agonist, on mRNA expression of NTFs using quantitative RT-PCR. Our data revealed that DOR activation with UFP512 enhanced mRNA expression of both BDNF and NGF, but not of GDNF. This effect could be largely attenuated by DOR antagonist, Naltrindole. A protein kinase $\mathrm{C}$ inhibitor, Calphostin C, completely blocked UFP-512 induced BDNF expression. In contrast, a protein kinase A inhibitor, H89, significantly suppressed UFP-512 induced NGF expression. Both Calphostin $\mathrm{C}$ and H89 had no appreciable effect on GDNF expression. These data suggest that the DOR activation up-regulates BDNF and NGF expression through differential protein kinase pathways in astrocytes, which may also form a component of molecular mechanisms underlying the DOR protection [114].

\section{Conclusion}

DOR was traditionally thought to

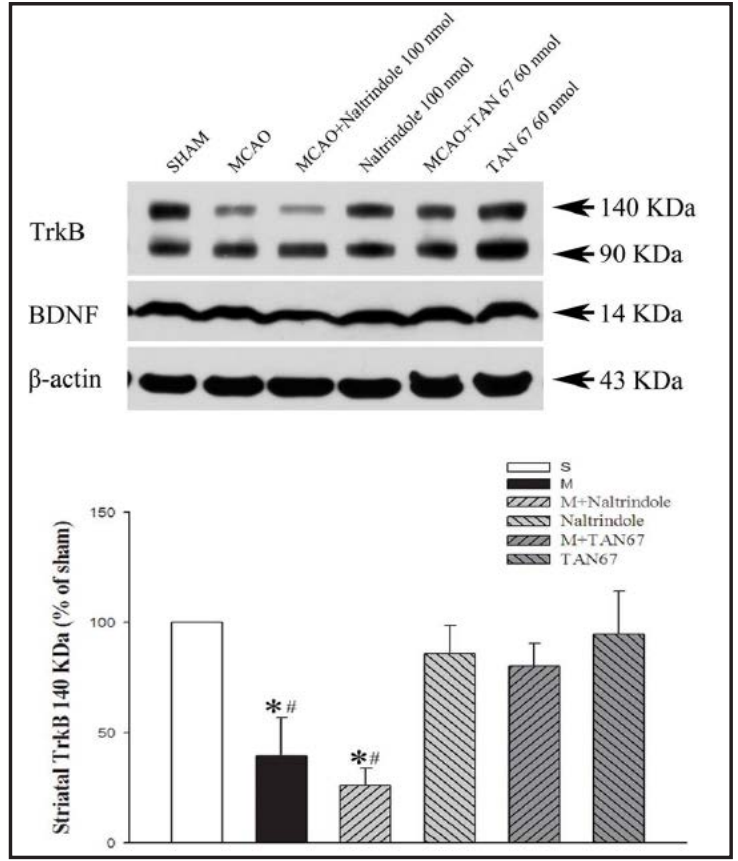

Fig. 5. Effects of DOR activation and inhibition on striatal TrkB at 24 hours after MCAO. Top panel, Representative Western blot images of TrkB expression in different groups. Bottom panel, Quantitative analysis of 140 KDa full-length TrkB (n=4). S, Sham control. M, MCAO. $* \mathrm{P}<0.05$ vs. the sham control. \#P<0.05 vs. $\mathrm{M}+\mathrm{TAN} 67$ (a DOR agonist). Note that the MCAO-induced changes and DOR effects are the same as those of the cortex. Cited from Tian et al. [110]. be primarily involved in modulating the transmission of messages along pain pathways. Most previous studies focused on its function in pain modulation and addiction. Therefore, little was known regarding its neural 
Sheng et al.: $\delta$-Opioid Receptor and BDNF-TrkB in Neuroprotection

function, along with major controversies on its role in the brain under hypoxic/ischemic conditions. Our serial studies have reconciled previous controversies, and demonstrated that DOR is a unique neuroprotector in the brain and plays an important role in neuroprotection against hypoxic and ischemic brain injury. Moreover, many other investigations have also shown DOR's neuroprotection against hypoxic/ischemic injury. Our mechanistic research has led us to paint a picture depicting cellular and molecular mechanisms underlying DOR neuroprotection. More recently, our data provide new evidence showing that DOR may display its protective role in the brain, especially the cortex and striatum, via neuronal and astrocytic BDNF-TrkB pathways. It is our belief that further comprehensive and in-depth research on DOR neuroprotection will eventually open a door for the prevention and treatment of stroke and other neurodegenerative diseases,such as Parkinson's disease, since previous clues and new molecular evidence [115-118] suggest that DOR activation may trigger an anti-parkinsonian effect.

\section{Acknowledgements}

This work was supported by Shanghai Key Laboratory of Acupuncture Mechanism and Acupoint Function (14DZ2260500), the National Natural Science Foundation of China (81590953, 81574053, 81303027, 81302197, 31071046), Science and Technology Commission of Shanghai Municipality (15441903800), JPSPMS (BL2014035), CSTSP (CE20155060, CE20165048), and Hainan Provincial Natural Science Foundation Innovative Research Team Project (2016CXTD010).

\section{Disclosure Statement}

The authors declare no conflicts of interest regarding the publication of this article.

\section{References}

1 Ma M, Qian H, Ghassemi F, Zhao P, Xia Y: Oxygen-sensitive delta-opioid receptor-regulated survival and death signals: novel insights into neuronal preconditioning and protection. J Biol Chem 2005;280:1620816218.

2 Chao D, Xia Y: Ionic storm in hypoxic/ischemic stress: can opioid receptors subside it? Prog Neurobiol 2010;90:439-470.

-3 He X, Sandhu HK, Yang Y, Hua F, Belser N, Kim DH, Xia Y: Neuroprotection against hypoxia/ischemia: deltaopioid receptor-mediated cellular/molecular events. Cell Mol Life Sci 2013;70:2291-2303.

4 Zhang JH, Xia Y, Haddad GG: Activation of $\delta$-opioid receptors protects cortical neurons from glutamate excitotoxic injury, Society for neuroscience online: SfN Abstract, Program no. 25:736, 1999.

5 Evans CJ, Keith DE, Jr., Morrison H, Magendzo K, Edwards RH: Cloning of a delta opioid receptor by functional expression. Science 1992;258:1952-1955.

-6 Kieffer BL, Befort K, Gaveriaux-Ruff C, Hirth CG: The delta-opioid receptor: isolation of a cDNA by expression cloning and pharmacological characterization. Proc Natl Acad Sci U S A 1992;89:12048-12052.

7 Chang KJ, Porreca F, Woods J: The Delta Receptor. Marcel Dekker Inc., 2003.

-8 Costantino CM, Gomes I, Stockton SD, Lim MP, Devi LA: Opioid receptor heteromers in analgesia. Expert Rev Mol Med 2012;14:e9.

- Lutz PE, Kieffer BL: The multiple facets of opioid receptor function: implications for addiction. Curr Opin Neurobiol 2013;23:473-479.

10 Giri AK, Hruby VJ: Investigational peptide and peptidomimetic mu and delta opioid receptor agonists in the relief of pain. Expert Opin Investig Drugs 2014;23:227-241.

11 Hayward NJ, McKnight AT, Woodruff GN: Neuroprotective effect of the kappa-agonist enadoline (CI-977) in rat models of focal cerebral ischaemia. Eur J Neurosci 1993;5:961-967. 


\section{Cellular Physiology Cell Physiol Biochem 2018;47:302-315 \begin{tabular}{l|l} 
DOI: 10.1159/000489808 & Ond 2018 The Author(s). Published by S. Karger AG, Basel \\
www.karger.com/cpb
\end{tabular}}

Sheng et al.: $\delta$-Opioid Receptor and BDNF-TrkB in Neuroprotection

12 Hayward NJ, McKnight AT, Woodruff GN: Brain temperature and the neuroprotective action of enadoline and dizocilpine in the gerbil model of global ischaemia. Eur J Pharmacol 1993;236:247-253.

13 Mayfield KP, D’Alecy LG: Delta-1 opioid agonist acutely increases hypoxic tolerance. J Pharmacol Exp Ther 1994;268:683-688.

14 Mayfield KP, D’Alecy LG: Delta-1 opioid receptor dependence of acute hypoxic adaptation. J Pharmacol Exp Ther 1994;268:74-77.

15 Mayfield KP, Hong EJ, Carney KM, D’Alecy LG: Potential adaptations to acute hypoxia: Hct, stress proteins, and set point for temperature regulation. Am J Physiol 1994;266:R1615-1622.

16 Baskin DS, Kieck CF, Hosobuchi Y: Naloxone reversal and morphine exacerbation of neurologic deficits secondary to focal cerebral ischemia in baboons. Brain Res 1984;290:289-296.

17 Hosobuchi Y, Baskin DS, Woo SK: Reversal of induced ischemic neurologic deficit in gerbils by the opiate antagonist naloxone. Science 1982;215:69-71.

18 Phillis JW, DeLong RE, Towner JK: Naloxone enhances cerebral reactive hyperemia in the rat. Neurosurgery 1985;17:596-599.

19 Skarphedinsson J0, Thoren P: Endorphin mechanisms are responsible for the beneficial effects of opioid antagonists on cerebral function during relative cerebral ischaemia in rats. Acta Physiol Scand 1988;132:281-288.

20 Xia Y, Jiang C, Haddad GG: Oxidative and glycolytic pathways in rat (newborn and adult) and turtle brain: role during anoxia. Am J Physiol 1992;262:R595-603.

21 Xia Y, Haddad GG: Major difference in the expression of delta- and mu-opioid receptors between turtle and rat brain. J Comp Neurol 2001;436:202-210.

-22 Hughes J, Smith TW, Kosterlitz HW, Fothergill LA, Morgan BA, Morris HR: Identification of two related pentapeptides from the brain with potent opiate agonist activity. Nature 1975;258:577-580.

-23 Cox BM, Goldstein A, Hi CH: Opioid activity of a peptide, beta-lipotropin-(61-91), derived from betalipotropin. Proc Natl Acad Sci U S A 1976;73:1821-1823.

24 Goldstein A: Opioid peptides endorphins in pituitary and brain. Science 1976;193:1081-1086.

25 Snyder SH, Pasternak GW: Historical review: Opioid receptors. Trends Pharmacol Sci 2003;24:198-205.

26 Noda M, Teranishi Y, Takahashi H, Toyosato M, Notake M, Nakanishi S, Numa S: Isolation and structural organization of the human preproenkephalin gene. Nature 1982;297:431-434.

27 Civelli O, Douglass J, Goldstein A, Herbert E: Sequence and expression of the rat prodynorphin gene. Proc Natl Acad Sci U S A 1985;82:4291-4295.

28 Nakanishi S, Inoue A, Kita T, Nakamura M, Chang AC, Cohen SN, Numa S: Nucleotide sequence of cloned cDNA for bovine corticotropin-beta-lipotropin precursor. Nature 1979;278:423-427.

29 Martin WR: Opioid antagonists. Pharmacol Rev 1967;19:463-521.

30 Goldstein A, Lowney LI, Pal BK: Stereospecific and nonspecific interactions of the morphine congener levorphanol in subcellular fractions of mouse brain. Proc Natl Acad Sci U S A 1971;68:1742-1747.

-31 Pert CB, Snyder SH: Opiate receptor: demonstration in nervous tissue. Science 1973;179:1011-1014.

-32 Simon EJ, Hiller JM, Edelman I: Stereospecific binding of the potent narcotic analgesic (3H) Etorphine to rat-brain homogenate. Proc Natl Acad Sci U S A 1973;70:1947-1949.

-33 Chen Y, Mestek A, Liu J, Hurley JA, Yu L: Molecular cloning and functional expression of a mu-opioid receptor from rat brain. Mol Pharmacol 1993;44:8-12.

-34 Wang JB, Imai Y, Eppler CM, Gregor P, Spivak CE, Uhl GR: mu opiate receptor: cDNA cloning and expression. Proc Natl Acad Sci U S A 1993;90:10230-10234.

35 Meng F, Xie GX, Thompson RC, Mansour A, Goldstein A, Watson SJ, Akil H: Cloning and pharmacological characterization of a rat kappa opioid receptor. Proc Natl Acad Sci U S A 1993;90:9954-9958.

-36 Minami M, Toya T, Katao Y, Maekawa K, Nakamura S, Onogi T, Kaneko S, Satoh M: Cloning and expression of a cDNA for the rat kappa-opioid receptor. FEBS Lett 1993;329:291-295.

37 Law P-Y, Loh HH: Regulation of Opioid Receptor Activities. J Pharmacol Exp Ther 1999;289:607.

-38 Audet N, Gales C, Archer-Lahlou E, Vallieres M, Schiller PW, Bouvier M, Pineyro G: Bioluminescence resonance energy transfer assays reveal ligand-specific conformational changes within preformed signaling complexes containing delta-opioid receptors and heterotrimeric G proteins. J Biol Chem 2008;283:15078-15088.

-39 Pasternak GW: Multiple opiate receptors: deja vu all over again. Neuropharmacology 2004;47 Suppl 1:312323. 


\section{Cellular Physiology Cell Physiol Biochem 2018;47:302-315 \begin{tabular}{ll|l} 
DOI: 10.1159/000489808 & Ond Biochemistry & $\begin{array}{l}\text { 2018 The Author(s). Published by S. Karger AG, Basel } \\
\text { www.karger.com/cpb }\end{array}$
\end{tabular}}

Sheng et al.: $\delta$-Opioid Receptor and BDNF-TrkB in Neuroprotection

40 Ballet S, Pietsch M, Abell AD: Multiple ligands in opioid research. Protein Pept Lett 2008;15:668-682.

41 Feng Y, He X, Yang Y, Chao D, Lazarus LH, Xia Y: Current research on opioid receptor function. Curr Drug Targets 2012;13:230-246.

-42 Xia Y, Haddad GG: Major differences in CNS sulfonylurea receptor distribution between the rat (newborn, adult) and turtle. J Comp Neurol 1991;314:278-289.

43 Waldhoer M, Bartlett SE, Whistler JL: Opioid Receptors. Annu Rev Biochem 2004;73:953-990.

-44 Peng J, Sarkar S, Chang SL: Opioid receptor expression in human brain and peripheral tissues using absolute quantitative real-time RT-PCR. Drug Alcohol Depend 2012;124:223-228.

-45 Zhi F, Xue L, Shao N, Deng D, Kang X, Chao D, Xu Y, Wang R, Yang Y, Xia Y: delta-Opioid Receptor Activation and MicroRNA Expression in the Rat Heart Under Prolonged Hypoxia. Cell Physiol Biochem 2016;39:11181128.

46 Zhi F, Shao N, Xue L, Xu Y, Kang X, Yang Y, Xia Y: Characteristic MicroRNA Expression Induced by deltaOpioid Receptor Activation in the Rat Liver Under Prolonged Hypoxia. Cell Physiol Biochem 2017;44:22962309.

47 Lord JA, Waterfield AA, Hughes J, Kosterlitz HW: Endogenous opioid peptides: multiple agonists and receptors. Nature 1977;267:495-499.

48 Chang KJ, Cuatrecasas P: Multiple opiate receptors. Enkephalins and morphine bind to receptors of different specificity. J Biol Chem 1979;254:2610-2618.

49 Xia Y: Neural Functions of the Delta-Opioid Receptor; in Xia Y (ed), Cham : Springer International Publishing : Imprint: Springer, 2015.

50 Sofuoglu M, Portoghese PS, Takemori AE: Differential antagonism of delta opioid agonists by naltrindole and its benzofuran analog (NTB) in mice: evidence for delta opioid receptor subtypes. J Pharmacol Exp Ther 1991;257:676-680.

51 Portoghese PS, Sultana M, Nelson WL, Klein P, Takemori AE: Delta opioid antagonist activity and binding studies of regioisomeric isothiocyanate derivatives of naltrindole: evidence for delta receptor subtypes. J Med Chem 1992;35:4086-4091.

52 Van Rijn RM, DeFriel JN, Whistler JL: Pharmacological traits of delta opioid receptors: pitfalls or opportunities? Psychopharmacology (Berl) 2013;228:1-18.

53 Gao H, Chao DM, Villarreal SJ, Yiu D, Wen GQ, Xia Y, Yao F, Wang Q, Xia Y: The various functions of opioids in pathophysiological conditions; in Xia Y (ed) Neural functions of the delta-opioid receptor. New York, Heidelberg, Dordrecht, London, Springer, 2015, pp 631-685.

54 Balboni G, Salvadori S, Guerrini R, Negri L, Giannini E, Jinsmaa Y, Bryant SD, Lazarus LH: Potent delta-opioid receptor agonists containing the Dmt-Tic pharmacophore. J Med Chem 2002;45:5556-5563.

55 Chao D, Bazzy-Asaad A, Balboni G, Xia Y: delta-, but not mu-, opioid receptor stabilizes K(+) homeostasis by reducing $\mathrm{Ca}(2+)$ influx in the cortex during acute hypoxia. J Cell Physiol 2007;212:60-67.

56 Chao D, Bazzy-Asaad A, Balboni G, Salvadori S, Xia Y: Activation of DOR attenuates anoxic K+ derangement via inhibition of Na+ entry in mouse cortex. Cereb Cortex 2008;18:2217-2227.

57 Chao D, Balboni G, Lazarus LH, Salvadori S, Xia Y: Na+ mechanism of delta-opioid receptor induced protection from anoxic K+ leakage in the cortex. Cell Mol Life Sci 2009;66:1105-1115.

58 Kang X, Chao D, Gu Q Ding G, Wang Y, Balboni G, Lazarus LH, Xia Y: $\delta$-opioid receptors protect from anoxic disruption of $\mathrm{Na}(+)$ and $\mathrm{K}(+)$ homeostasis via $\mathrm{Na}(+)$ channel regulation. Cellular and molecular life sciences : CMLS 2009;66:3505-3516.

59 Baskin DS, Hosobuchi Y: Naloxone reversal of ischaemic neurological deficits in man. Lancet 1981;2:272275.

60 Iwai T, Niwa M, Nakashima M, Kambara T, Yamada H, Tsurumi K, Nozaki M: Effect of opioids on delayed neuronal death in the gerbil hippocampus. Life Sci 1992;50:Pl239-244.

61 Endoh H, Taga K, Yamakura T, Sato K, Watanabe I, Fukuda S, Shimoji K: Effects of naloxone and morphine on acute hypoxic survival in mice. Crit Care Med 1999;27:1929-1933.

-62 Adams HP, Jr., Olinger CP, Barsan WG, Butler MJ, Graff-Radford NR, Brott TG, Biller J, Damasio H, Tomsick T, Goldberg M, et al. .: A dose-escalation study of large doses of naloxone for treatment of patients with acute cerebral ischemia. Stroke 1986;17:404-409.

63 Olinger CP, Adams HP, Jr., Brott TG, Biller J, Barsan WG, Toffol GJ, Eberle RW, Marler JR: High-dose intravenous naloxone for the treatment of acute ischemic stroke. Stroke 1990;21:721-725. 


\section{Cellular Physiology Cell Physiol Biochem 2018;47:302-315 \begin{tabular}{l|l|l} 
DOI: 10.1159/000489808 & Ond 2018 The Author(s). Published by S. Karger AG, Basel \\
www.karger.com/cpb
\end{tabular}}

Sheng et al.: $\delta$-Opioid Receptor and BDNF-TrkB in Neuroprotection

-64 Schultz JJ, Hsu AK, Gross GJ: Ischemic preconditioning and morphine-induced cardioprotection involve the delta (delta)-opioid receptor in the intact rat heart. J Mol Cell Cardiol 1997;29:2187-2195.

65 Takasaki Y, Wolff RA, Chien GL, van Winkle DM: Met5-enkephalin protects isolated adult rabbit cardiomyocytes via delta-opioid receptors. Am J Physiol 1999;277:H2442-2450.

66 Gross GJ: Role of opioids in acute and delayed preconditioning. J Mol Cell Cardiol 2003;35:709-718.

67 Wang J, Gao Q, Sun GQ, Zhou HO, Xia Q: Delta-opioid receptor mediates the cardioprotective effect of ischemic postconditioning. Zhongguo Ying Yong Sheng Li Xue Za Zhi 2008;24:184-189.

-68 Huang MH, Nguyen V, Wu Y, Rastogi S, Lui CY, Birnbaum Y, Wang HQ Ware DL, Chauhan M, Garg N, Poh KK, Ye L, Omar AR, Tan HC, Uretsky BF, Fujise K: Reducing ischaemia/reperfusion injury through delta-opioidregulated intrinsic cardiac adrenergic cells: adrenopeptidergic co-signalling. Cardiovasc Res 2009;84:452460.

69 Fraessdorf J, Hollmann MW, Hanschmann I, Heinen A, Weber NC, Preckel B, Huhn R: Role of Endogenous Opioid System in Ischemic-Induced Late Preconditioning. PLoS One 2015;10:e0134283.

70 Headrick JP, See Hoe LE, Du Toit EF, Peart JN: Opioid receptors and cardioprotection - 'opioidergic conditioning' of the heart. Br J Pharmacol 2015;172:2026-2050.

71 Maslov LN, Naryzhnaya NV, Prokudina ES, Kolar F, Gorbunov AS, Zhang Y, Wang H, Tsibulnikov SY, Portnichenko AG, Lasukova TV, Lishmanov YB: Preserved cardiac mitochondrial function and reduced ischaemia/reperfusion injury afforded by chronic continuous hypoxia: role of opioid receptors. Clin Exp Pharmacol Physiol 2015;42:496-501.

-72 Choi DW, Viseskul V: Opioids and non-opioid enantiomers selectively attenuate N-methyl-D-aspartate neurotoxicity on cortical neurons. Eur J Pharmacol 1988;155:27-35.

73 Lockhart BP, Soulard P, Benicourt C, Privat A, Junien JL: Distinct neuroprotective profiles for sigma ligands against N-methyl-D-aspartate (NMDA), and hypoxia-mediated neurotoxicity in neuronal culture toxicity studies. Brain Res 1995;675:110-120.

-74 Jiang C, Xia Y, Haddad GG: Role of ATP-sensitive K+ channels during anoxia: major differences between rat (newborn and adult) and turtle neurons. J Physiol 1992;448:599-612.

75 Nilsson GE, Lutz PL: Anoxia tolerant brains. J Cereb Blood Flow Metab 2004;24:475-486.

76 Milton SL, Prentice HM: Beyond anoxia: the physiology of metabolic downregulation and recovery in the anoxia-tolerant turtle. Comp Biochem Physiol A Mol Integr Physiol 2007;147:277-290.

-77 Xia Y, Haddad GG: Neuroanatomical distribution and binding properties of saxitoxin sites in the rat and turtle CNS. J Comp Neurol 1993;330:363-380.

78 Wilson AM, Kriegstein AR: Turtle cortical neurons survive glutamate exposures that are lethal to mammalian neurons. Brain Res 1991;540:297-301.

79 Zhang JH, Haddad G, Xia Y: delta-, but not mu- and kappa-, opioid receptor activation protects neocortical neurons from glutamate-induced excitotoxic injury. 2001.

-80 Zhang J, Gibney GT, Zhao P, Xia Y: Neuroprotective role of delta-opioid receptors in cortical neurons. Am J Physiol Cell Physiol 2002;282:C1225-1234.

81 Borlongan CV, Oeltgen PR, Su TP, Wang Y: Delta opioid peptide (DADLE) protects against ischemia reperfusion damage in the striatum and cerebral cortex. Soc Neurosci Abstr 1999;24:979.

82 Blurton PA, Broadhurst AM, Wood MD, Wyllie MG: Is there a common, high-affinity opioid binding site in rat brain? J Recept Res 1986;6:85-93.

83 Chao D, Qian H, Ghassemi F, Chen J, Xia Y: Transgenic overexpression of delta-opioid receptors protects the cortex from anoxic disruption of ionic homeostasis. Atlanta, Neuroscience Meeting Planner, Society for Neuroscience, Program No. 87.19/MM68, 2006.

84 Borlongan CV, Wang Y, Su TP: Delta opioid peptide (D-Ala 2, D-Leu 5) enkephalin: linking hibernation and neuroprotection. Front Biosci 2004;9:3392-3398.

85 Horiuchi T, Kawaguchi M, Sakamoto T, Kurita N, Inoue S, Nakamura M, Konishi N, Furuya H: The effects of the delta-opioid agonist SNC80 on hind-limb motor function and neuronal injury after spinal cord ischemia in rats. Anesth Analg 2004;99:235-240.

-86 Lim YJ, Zheng S, Zuo Z: Morphine preconditions Purkinje cells against cell death under in vitro simulated ischemia-reperfusion conditions. Anesthesiology 2004;100:562-568.

-87 Narita M, Kuzumaki N, Miyatake M, Sato F, Wachi H, Seyama Y, Suzuki T: Role of delta-opioid receptor function in neurogenesis and neuroprotection. J Neurochem 2006;97:1494-1505. 


\section{Cellular Physiology Cell Physiol Biochem 2018;47:302-315 \begin{tabular}{c|c|c|} 
DOI: 10.1159/000489808 & O 2018 The Author(s). Published by S. Karger AG, Basel \\
www.karger.com/cpb
\end{tabular}}

Sheng et al.: $\delta$-Opioid Receptor and BDNF-TrkB in Neuroprotection

-88 Iwata M, Inoue S, Kawaguchi M, Nakamura M, Konishi N, Furuya H: Effects of delta-opioid receptor stimulation and inhibition on hippocampal survival in a rat model of forebrain ischaemia. $\mathrm{Br} \mathrm{J}$ Anaesth 2007;99:538-546.

-89 Su DS, Wang ZH, Zheng YJ, Zhao YH, Wang XR: Dose-dependent neuroprotection of delta opioid peptide [D-Ala2, D-Leu5] enkephalin in neuronal death and retarded behavior induced by forebrain ischemia in rats. Neurosci Lett 2007;423:113-117.

90 Xiong LZ, Yang J, Wang Q Lu ZH: Involvement of delta-and mu-opioid receptors in the delayed cerebral ischemic tolerance induced by repeated electroacupuncture preconditioning in rats. Chin Med J (Engl) 2007;120:394-399.

-91 Charron C, Messier C, Plamondon H: Neuroprotection and functional recovery conferred by administration of kappa- and delta 1-opioid agonists in a rat model of global ischemia. Physiol Behav 2008;93:502-511.

-92 Govindaswami M, Brown SA, Yu J, Zhu H, Bishop PD, Kindy MS, Oeltgen PR: Delta 2-specific opioid receptor agonist and hibernating woodchuck plasma fraction provide ischemic neuroprotection. Acad Emerg Med 2008;15:250-257.

-93 Horiuchi T, Kawaguchi M, Kurita N, Inoue S, Sakamoto T, Nakamura M, Konishi N, Furuya H: Effects of deltaopioid agonist SNC80 on white matter injury following spinal cord ischemia in normothermic and mildly hypothermic rats. J Anesth 2008;22:32-37.

-94 Pamenter ME, Buck LT: delta-Opioid receptor antagonism induces NMDA receptor-dependent excitotoxicity in anoxic turtle cortex. J Exp Biol 2008;211:3512-3517.

-95 Borlongan CV, Hayashi T, Oeltgen PR, Su TP, Wang Y: Hibernation-like state induced by an opioid peptide protects against experimental stroke. BMC Biol 2009;7:31.

-96 Peng PH, Huang HS, Lee YJ, Chen YS, Ma MC: Novel role for the delta-opioid receptor in hypoxic preconditioning in rat retinas. J Neurochem 2009;108:741-754.

\$7 Zhu M, Li MW, Tian XS, Ou XM, Zhu CQ, Guo JC: Neuroprotective role of delta-opioid receptors against mitochondrial respiratory chain injury. Brain Res 2009;1252:183-191.

98 Johnson SM, Turner SM: Protecting motor networks during perinatal ischemia: the case for delta-opioid receptors. Ann N Y Acad Sci 2010;1198:260-270.

-99 Nandhu MS, Naijil G, Smijin S, Jayanarayanan S, Paulose CS: Opioid system functional regulation in neurological disease management. J Neurosci Res 2010;88:3215-3221.

100 Duan YL, Wang SY, Zeng QW, Su DS, Li W, Wang XR, Zhao Z: Astroglial reaction to delta opioid peptide [D-Ala2, D-Leu5] enkephalin confers neuroprotection against global ischemia in the adult rat hippocampus. Neuroscience 2011;192:81-90.

101 Turner SMF, Johnson SM: Delta-opioid receptor (DOR) activation prolongs respiratory motor output during oxygen-glucose deprivation (OGD) in neonatal rat spinal cord in vitro. Neuroscience 2011;187:70-83.

102 Wang S, Duan Y, Su D, Li W, Tan J, Yang D, Wang W, Zhao Z, Wang X: Delta opioid peptide [D-Ala2, D-Leu5] enkephalin (DADLE) triggers postconditioning against transient forebrain ischemia. Eur J Pharmacol 2011;658:140-144.

103 Yang L, Wang H, Shah K, Karamyan VT, Abbruscato TJ: Opioid receptor agonists reduce brain edema in stroke. Brain Res 2011;1383:307-316.

104 Gao CJ, Niu L, Ren PC, Wang W, Zhu C, Li YQ Chai W, Sun XD: Hypoxic preconditioning attenuates global cerebral ischemic injury following asphyxial cardiac arrest through regulation of delta opioid receptor system. Neuroscience 2012;202:352-362.

105 Zheng YJ, Wang XR, Chen HZ, Wu XJ, Zhao YH, Su DS: Protective effects of the delta opioid peptide [D-Ala2, D-Leu5] enkephalin in an ex vivo model of ischemia/reperfusion in brain slices. CNS Neurosci Ther 2012;18:762-766.

106 Feng Y, Chao D, He X, Yang Y, Kang X, L HL, Xia Y: A novel insight into neuroprotection against hypoxic/ ischemic stress. Sheng Li Xue Bao 2009;61:585-592.

107 Tian X, Hua F, Sandhu HK, Chao D, Balboni G, Salvadori S, He X, Xia Y: Effect of $\delta$-Opioid Receptor Activation on BDNF-TrkB vs. TNF- $\alpha$ in the Mouse Cortex Exposed to Prolonged Hypoxia. Int J Mol Sci 2013;14:1595915976.

108 Narumiya S, Ohno M, Tanaka N, Yamano T, Shimada M: Enhanced expression of full-length TrkB receptors in young rat brain with hypoxic/ischemic injury. Brain Res 1998;797:278-286. 


\section{Cellular Physiology Cell Physiol Biochem 2018;47:302-315 \begin{tabular}{l|l|l} 
DOI: 10.1159/000489808 & Ond 2018 The Author(s). Published by S. Karger AG, Basel \\
www.karger.com/cpb
\end{tabular} \\ Sheng et al.: $\delta$-Opioid Receptor and BDNF-TrkB in Neuroprotection}

109 Sun X, Zhou H, Luo X, Li S, Yu D, Hua J, Mu D, Mao M: Neuroprotection of brain-derived neurotrophic factor against hypoxic injury in vitro requires activation of extracellular signal-regulated kinase and phosphatidylinositol 3-kinase. Int J Dev Neurosci 2008;26:363-370.

110 Tian X, Guo J, Zhu M, Li M, Wu G, Xia Y: $\delta$-Opioid Receptor Activation Rescues the Functional TrkB Receptor and Protects the Brain from Ischemia-Reperfusion Injury in the Rat. PLoS One 2013;8:e69252.

111 Huang EJ, Reichardt LF: Neurotrophins: roles in neuronal development and function. Annu Rev Neurosci 2001;24:677-736.

112 Gomes JR, Costa JT, Melo CV, Felizzi F, Monteiro P, Pinto MJ, Inacio AR, Wieloch T, Almeida RD, Graos M, Duarte CB: Excitotoxicity downregulates TrkB.FL signaling and upregulates the neuroprotective truncated TrkB receptors in cultured hippocampal and striatal neurons. J Neurosci 2012;32:4610-4622.

113 Vidaurre OG, Gascon S, Deogracias R, Sobrado M, Cuadrado E, Montaner J, Rodriguez-Pena A, Diaz-Guerra $\mathrm{M}$ : Imbalance of neurotrophin receptor isoforms TrkB-FL/TrkB-T1 induces neuronal death in excitotoxicity. Cell Death Dis 2012;3:e256.

114 Liang J, Teng S, Chao D, Kim D, Xia Y: Activation of the delta-opioid receptor up-regulates expression of neurotrophic factors in astrocytes. Washington, DC, Neuroscience Meeting Planner, Society for Neuroscience, 2011, Program No. 673.22.

115 Borlongan CV, Su TP, Wang Y: Treatment with delta opioid peptide enhances in vitro and in vivo survival of rat dopaminergic neurons. Neuroreport 2000;11:923-926.

-116 Borlongan CV, Su TP, Wang Y: Delta opioid peptide augments functional effects and intrastriatal graft survival of rat fetal ventral mesencephalic cells. Cell Transplant 2001;10:53-58.

117 Chen T, Li J, Chao D, Sandhu HK, Liao X, Zhao J, Wen G, Xia Y: delta-Opioid receptor activation reduces alpha-synuclein overexpression and oligomer formation induced by MPP(+) and/or hypoxia. Exp Neurol 2014;255:127-136.

118 Xu Y, Zhi F, Shao N, Wang R, Yang Y, Xia Y: Cytoprotection against Hypoxic and/or MPP(+) Injury: Effect of delta-Opioid Receptor Activation on Caspase 3. Int J Mol Sci 2016;17: (8). pii: E1179. 